\title{
ANALISIS PENGGUNAAN PENERAPAN SISTEM MANAJEMEN KESELAMATAN DAN KESEHATAN KERJA (SMK3) PADA PROYEK PEMBANGUNAN RSUD SUNAN KALIJAGA DEMAK (Studi Kasus Pada Pembangunan RSUD Sunan Kalijaga di Demak)
}

\author{
Hari Setijo P. ${ }^{1}$, Bambang Tutuko. ${ }^{1}$, Wildan Abied Z. ${ }^{2}$, Suci Febryta. ${ }^{2}$ \\ ${ }^{1}$ Jurusan Teknik Sipil Universitas Semarang \\ 2Jurusan Teknik Sipil Universitas Semarang
}

\begin{abstract}
Occupational Health and Safety Management System (SMK 3) is a protection system that has been prepared and designed for workers and construction services to minimize and avoid the risk of loss of time, material and the risk of workplace accidents that will be experienced by workers work. Guidelines for the Implementation of the Occupational Safety and Health Management System (SMK3) in Indonesia are found in the Minister of Manpower Regulation Number: PER.05 / MEN / 1996, Minister of Public Works Regulation No. 9 of 2008 concerning Guidelines for Construction Work Safety and Safety Management System (SMK3) in the Field of Public Works, and PP No. 50 of 2012 concerning Application of Management Systems

Occupational Health and Safety. The purpose of this study was to evaluate the implementation of the Occupational Safety and Health Management System, and to find out the steps in the implementation of the Occupational Safety and Health Management System in the Project for the Construction of the Regional General Hospital of Sunan Kalijaga Demak. Data processing is done by compiling and discussing the results of the questionnaire that has been distributed to the respondents, as well as literature studies as supporting data. The results of the study show that the overall guidelines for the Occupational Safety and Safety Management System (SMK3) have been implemented very well.
\end{abstract}

Keywords: SMK 3, Guidelines, RSUD Sunan Kalijaga.

\begin{abstract}
Abstrak
Sistem Manajemen Keselamatan dan Kesehatan Kerja (SMK 3) adalah sebuah sistem perlindungan yang sudah dipersiapkan dan dirancang bagi para tenaga kerja dan jasa konstruksi untuk meminimalisasi dan menghindarkan diri dari resiko kerugian waktu, materi dan dari resiko kecelakaan kerja yang akan dialami oleh para tenaga kerja. Pedoman Penerapan Sistem Manajemen Keselamatan dan Kesehatan Kerja (SMK3) di Indonesia terdapat pada Peraturan Menteri Tenaga Kerja Nomor : PER.05/MEN/1996, Peraturan Mentri PU No. 9 Tahun 2008 tentang pedoman Sistem Manajemen Keselamatan Dan Keselamatan Kerja ( SMK3 ) Konstruksi Bidang Pekerjaan Umum, dan PP No. 50 Tahun 2012 tentang Penerapan Sistem Manajemen Keselamatan dan Kesehatan Kerja. Tujuan Dalam Penelitian Ini adalah untuk mengevaluasi penerapan Sistem Manajemen Keselamatan dan Kesehatan Kerja, dan untuk mengetahui langkah-langkah penerapan Sistem Manajemen Keselamatan dan Kesehatan Kerja di lingkungan Proyek Pembangunan Rumah Sakit Umum Daerah Sunan Kalijaga Demak. Pengolahan data dilakukan dengan menyusun dan membahas hasil dari kuesoner yang sudah di sebar kepada para responden, serta studi literatur sebagai data pendukung. Hasil dari penelitian menunjukan bahwa secara keseluruhan pedoman Sistem Manajemen Keselamatan Dan Keselamatan Kerja ( SMK3 ) sudah diterapkan dengn sangat baik.
\end{abstract}

Kata Kunci : SMK 3, Pedoman, RSUD Sunan Kalijaga

\section{PENDAHULUAN}

\section{Latar Belakang}

Perkembangan dunia konstruksi di Indonesia mengalami banyak perkembangan terutama dalam pembangunan infrastruktur, banyaknya proyek-proyek besar yang sedang dikerjakan sehingga menuntut para pekerja lebih keras,maka dari itu perusahaan-perusahaan dalam bidang jasa konstruksi dituntut agar lebih memperhatikan manajemen konstruksi khususnya manajemen resiko 
bidang K3 (Kesehatan dan Keselamatan Kerja).Cidera atau kerugian materi yang diakibatkan oleh kecelakaan, oleh karena itu tujuan utama penerapan sistem manajemen keselamatan dan kesehatan kerja ( SMK3 ) agar kecelakaan kerja menurun. Karena itu fenomena kecelakaan, faktor penyebab, serta cara efektif untuk pencegahan dipelajari oleh para ahli K3. Salah satu diantaranya pola pikir yang masih tradisional dimana kecelakaan dianggap sebagai musibah sehingga masyarakat bersifat pasrah ( Soehatman Ramli, 2010:6). Menurut A2K4I ( Asosiasi Ahli Keselamatan dan Kesehatan Konstruksi Indonesia) Sejak 1 Agustus 2017 hingga awal 2018, tercatat telah terjadi lebih dari 10 kasus kecelakaan konstruksi di proyek yang mengakibatkan sedikitnya empat pekerja meninggal dunia dan 11 pekerja lainnya menderita cidera, itu artinya masih banyak tenaga kerja di indonesia yang kurang dan bahkan tidak memperhatikan manajemen resiko bidang K3 (Kesehatan dan Keselamatan Kerja). Setiap pekerjaan konstruksi bangunan harus diusahakan pencegahan atau di kurangi terjadinya kecelakaan atau sakit akibat kerja terhadap tenaga kerjanya. Tindakan pencegahan harus dilakukan untuk menjamin bahwa peralatan perancah, alat-alat kerja, bahanbahan dan benda-benda lainnya tidak dilemparkan, diluncurkan atau dijatuhkan ke bawah dari tempat yang tinggi sehingga dapat menyebabkan kecelakaan ( Peraturan Menteri Tenaga Kerja dan Transmigrasi No.Per.01/Men/1980).

\section{Rumusan Masalah}

Berdasarkan latar belakang di atas maka rumusan masalah yang akan diteliti adalah sebagai berikut:

1. Dampak resiko apa saja yang terjadi jika Sistem Manajemen Keselamatan dan Kesehatan Kerja (SMK3) tidak diterapkan pada pelaksanaan Proyek Pembangunan Gedung Rumah Sakit Umum Daerah Sunan Kalijaga Demak?

2. Bagaimana Penerapan Sistem Manajemen Keselamatan dan Kesehatan Kerja (SMK3) di lingkungan Proyek Pembangunan Rumah Sakit Umum Daerah Sunan Kalijaga Demak?

Tujuan Penelitian

Tujuan yang ingin dicapai penulis antara lain :

1. Untuk mengevaluasi penerapan Sistem Manajemen SMK3 di lingkungan Proyek Pembangunan Rumah Sakit Umum Daerah Sunan Kalijaga Demak

2. Untuk mengetahui langkah-langkah penerapan Sistem Manajemen Keselamatan dan Kesehatan Kerja SMK3 di lingkungan Proyek Pembangunan Rumah Sakit Umum Daerah

Manfaat Penelitian

Manfaat pembahasan dalam penelitian ini adalah :

1. Dapat memahami pentingnya penerapan SMK3 pada sebuah proyek konstruksi.

2. Dapat mengetahui bagaimana cara penataan sistem SMK3 yang benar pada sebuah proek.

3. Penelitian ini dapat bermanfaat bagi semua pihak dalam bidang konstruksi agar selalu merencanakan manajemen konstruksi terutama dalam penerapan Sistem Manajemen Keselamatan dan Kesehatan Kerja (SMK3)

4. Sebagai tambahan ilmu bagi pembaca tetntang dalam penerapan Sistem Manajemen Keselamatan dan Kesehatan Kerja (SMK3) pada sebuah proyek

\section{TINJAUAN PUSTAKA}

\section{Pengertian Keselamatan dan Kesehatan Kerja K3}

Undang-Undang yang mengatur tentang keselamatan dan kesehatan kerja adalah undang-undang No. 13 tahun 2003 tentang ketenagakerjaan khususnya paragraf 5 tentang keselamatan dan kesehatan kerja, pasal 86 dan 87. Keselamatan dan kesehatan kerja merupakan proses perlindungan pekerja dalam kegiatan yang dilakukan pekerja pada suatu perusahaan atau tempat kerja yang menyangkut resiko baik jasmani dan rohani para pekerja. Perlindungan bagi pekerja merupakan kewajiban perusahaan demi menjaga lingkungan dan mencegah terjadinya kecelakaan kerja.

\section{Faktor Penyebab Kecelakaan Kerja}

Menurut Bennett dalamSantoso (2004) terdapat empat faktor bergerak dalam satu kesatuan berantai yang dapat menyebabkan kecelakaan, yaitu : lingkungan, peralatan, bahaya dan manusia. Ada beberapa sebab yang memungkinkan terjadinya kecelakaan dan gangguan kesehatan pegawai (Mangkunegara, 2001) diantaranya yaitu :

1. Keadaan Tempat Lingkungan Kerja

2. Pengaturan Udara

3. Pengaturan Penerangan

4. Pemakaian Peralatan Kerja

5. Kondisi Fisik dan Mental Pegawai 
Sistem Manajemen Keselamatan dan Kesehatan Kerja (SMK 3)

Manajemen dalam bahasa Inggris "management" dengan kata kerja to manage yang secara umum berarti mengurusi atau mengelola.Menurut Robbins dan Coulter (2007) manajemen adalah proses pengoordinasian kegiatan-kegiatan pekerjaan sehingga pekerjaan tersebut terselesaikan secara efisien dan efektif dengan dan melalui orang lain. Efisiensi mengacu pada memperoleh output terbesar dengan input terkecil; digambarkan sebagai "melakukan segala sesuatu secara benar." Sedangkan efektivitas mengacu pada menyelesaikan kegiatan-kegiatan sehingga sasaran organisasi dapat tercapai; digambarkan sebagai "melakukan segala sesuatu yang benar".

Sistem Manajemen Keselamatan dan Kesehatan Kerja (SMK3) adalah sebuah sistem perlindungan yang sudah dipersiapkan dan dirancang bagi para tenaga kerja dan jasa konstruksi untuk meminimalisasi dan menghindarkan diri dari resiko kerugian waktu, materi dan dari resiko kecelakaan kerja yang akan dialami oleh para tenaga kerja. Banyaknya kasus kecelakaan kerja yang terjadi di Indonesia menimbulkan sebuah fakta bahwa masih banyak perusahaan-perusahaan pada bidang jasa konstruksi baik besar maupun keci, masih kurang memperhatikan betapa pentingnya penerapan SMK3 pada suatu proyek, maka dari itu perlunya kesadaran yang besar baik dari pihak penyedia jasa maupu para pekerja agar lebih mementingkan keselamatan kerja.

Pedoman Penerapan Sistem Manajemen Keselamatan dan Kesehatan Kerja (SMK3) di Indonesia

Pekerjaan Konstruksi tidak hanya terjadi di negara Indonesia saja tetapi kegiatan tersebut ada di seluruh dunia dan dalam penerapan sistem manajemen keselamatan dan kesehatan kerja (SMK3) berbeda beda sesuai dengan perturan yang berlaku dalam negara tersebut. Di negara Indonesia penerapan (SMK3) diatur dalam Peraturan Menteri Tenaga Kerja Nomor : PER.05/MEN/1996. Disebutkan didalam Peraturan Menteri Tenaga Kerja Nomor : PER.05/MEN/1996 bahwa sistem manajemen keselamatan dan kesehatan kerja (SMK3) adalah bagian dari manajemen secara keseluruhan meliputi struktur organisasi, perencanaan, tanggung jawab, pelaksanaan prosedur, proses dan sumber daya yang dibutuhkan bagi pengembangan penerapan, pencapaian, pengkajian dan pemeliharaan kebijakan keselamatan dan kesehatan kerja dalam rangka pengendalian resiko yang berkaitan dengan kegiatan kerja guna terciptanya tempat kerja yang aman, efisien dan produtif.

Peraturan Mentri PU No. 9 Tahun 2008 tentang pedoman sistem Manajemen Keselamatan Dan Keselamatan Kerja ( SMK3 ) Konstruksi Bidang Pekwwejaan Umum

Sistem manajemen keselamatan kerja dan kesehatan kerja (SMK3) adalah bagian dari sistem manajemen secara keseluruhan yang meliputi strktur organisasi, perencanaan, tanggung jawab, pelaksanaan, prosedur, proses dan sumbe daya yang dibutuhkan bagi pengembang penerapan, pencapaian, pengkajian, dan pemeliharaan kebijakan kesekeselamaan dan kesehatan keja guna terciptanya tempat kerja yang aman, efisien dan produktif.

SMK3 konstruksi bidang pekerjaan umum adalah SMK3 pada sektor jasa konstruksi yang berhubungan dengan kepentingan umum ( masyarakat ) antara lain pekerjaan kontruksi jalan, jembatan, bangungan gedung fasilitas umum, sistem penyediaan air minum dan pipanya, drainase, pengelolaan sampah, pengaman pantai, irigasi, bendung, wduk, dan lainnya.

PP No. 50 Tahun 2012 tentang Penerapan Sistem Manajemen Keselamatan dan Kesehatan Kerja

Sistem Manajemen Keselamatan dan Kesehatan Kerja yang selanjutnya disingkat SMK3 adalah bagian dari Sistem Manajemen perusahaan secara keseluruhan dalam rangka pengendalian risiko yang berkaitan dengan kegiatan kerja guna terciptanya tempat kerja yang aman, efisien, dan produktif. Mengapa perlu adanya sistem SMK3? Sistem manajemen diperlukan untuk meningkatkan upaya $\mathrm{K} 3$ yang dijalankan dalam perusahaan agar berjalan secara efisien dan efektif.

Menurut PP No. 50/2012, penerapan SMK3 bertujuan untuk :

a) Meningkatkan efektifitas perlindungan keselamatan dan kesehatan kerja yang terencana, terukur, terstruktur, dan terintregasi.

b) Mencegah dan mengurangi kecelakan kerja dan penyakit akibat kerja dengan melibatkan unsur manajemen, pekerja/buruh, dan atau serikat pekerja.

c) Menciptakan tempat kerja yang aman, nyaman, dan efisien untuk mendorong produktifitas.

K3 Pada Bangunan Gedung

Menurut UNDANG-UNDANG REPUBLIK INDONESIA NOMOR 28 TAHUN 2002 TENTANG BANGUNAN GEDUNG Bangunan Gedung adalah wujud fisik hasil pekerjaan konstruksi yang menyatu dengan tempat kedudukannya, sebagian atau seluruhnya berada di atas dan/atau di dalam tanah dan/atau air, yang berfungsi sebagai tempat manusia melakukan kegiatannya, baik untuk hunian atau tempat tinggal, kegiatan keagamaan, kegiatan usaha, kegiatan sosial, budaya, maupun kegiatan khusus.Industri konstruksi merupakan sektor industri yang mempunyai tingkat risiko tinggi 
baik dari segi risiko usaha maupun risiko keselamatan kerja dan kesehatan. Berdasarkan data dari International Labor Organization (ILO) yang dikutip dalam Bisnis Indonesia (22 Januari 2010) menyebutkan setidaknya ada 1,1 juta kasus kematian setiap tahunnya di dunia, akibat kecelakaan kerja atau penyakit yang ditimbulkan lingkungan kerja.King dan Hudson (1985) menyatakan bahwa kematian pada proyek konstruksi di negara-negara berkembang lebih tinggi 3 kali lipat dibandingkan dengan di negara-negara maju sebagai akibat penegakan hukum yang sangat lemah. Tingginya tingkat risiko ini akan berpengaruh terhadap keseluruhan tingkat keberhasilan pekerjaan konstruksi. Beberapa bahaya yang mungkin terjadi pada proyek pembangunan gedung, ialah : Terjatuh dari ketinggian, Terkena serpihan paku atau tertusuk patahan besi tulangan, Terbentur skafollding, Tertimpa material seperti besi dari atas. Maka dari itu perlu sarana pelengkap bagi para pelaku kerja dan demi kenyamanan pekerjaan dalam proyek konstruksi seperti : Tabung pemadam kebakaran, Pagar pengaman, Rambu-rambu proyek, Jaring Pengaman, Peralatan P3K.

\section{Pengendalian Resiko}

Pengendalian resiko merupakan suatu hierarki (dilakukan berurutan sampai dengan tingkat resiko/bahaya berkurang menuju titik yang aman) hierarki pengendalian tersebuat antara lain eliminasi, subtitusi, perencanaan administrasi dan alat pelindung diri (APD). Cara pengendalian resiko dilakukan melalui :

a) Eliminasi

b) Substitusi

c) Perencanaan administrasi

d) Alat Pelindung Diri ( APD

\section{METODOLOGI}

\section{Pengertian Metodologi Penelitian}

Metodologi penelitian adalah sekumpulan peraturan, kegiatan dan prosedur / rangkain kegiatan pelaksanaan penelitian yang digunakan oleh pelaku ilmu disilin. Metodologi adalah analisis teoritis mengenai suatu cara atau metode dan penelitian adalah suatu penyelidikan yang sistematis untuk meningkatkan pengetahuan ataupun untuk menyelidiki masalah tertentu secara sistematis.

Penelitian memiliki tujuan yang berfungsi sebagai penetap jalur agar kegiatan penelitian tidak lepas dari tujuan yaitu pemecahan masalah. Sebuah penelitian juga harus disusun secara skematis dan terencana mulai dari persiapan sampai penyelesaian dengan aturan yang benar.

\section{Jenis Penelitian}

Metode Penelitian yang digunakan adalah dengan metode survei dengan tujuan mendeskripsikan sebuah variabel. Penelitian ini berisikan tentang analisa penggunaan peneraapansistem manajemen keselamatan dan kesehatan kerja (SMK3) pada Proyek Pembangunan Gedung Rumah Sakit Sunan Kalijaga Demak.

\section{Tempat dan Waktu Penelitian}

Fokus penelitian ini dilakukan pada Proyek Pembangunan Gedung Rumah Sakit Sunan Kalijaga Demak. Proyek ini memiliki tanah seluas $40.549 \mathrm{~m}$ dengan luas bangunan 9.930,34 dan berlokasi di Jl. Sultan Fatah 669/50 Bintaro,Kecamatan Demak, Kabupaten Demak Jawa Tengah. Terdiri dari 3 lantai dan dibangun oleh Pemerintah Daerah Kabupaten Demak

\section{Teknik Pengumpulan Data}

Metode yang digunakan dalam pengumpulan data ialah data primer dan sekunder. Data primer merupakan data yang diperoleh dari penyebaran kuesioner yang berisikan pertanyaan-pertanyaan yang berkaitan dengan penerapan sistem manajemen keselamatan dan kesehatan kerja (SMK3). Sedangkan data sekunder diperoleh dari literatur buku dan media elektronik.

\section{Sumber Data}

Sumber data ini diperoleh dari PT. SEMBILAN-SEMBILAN CAHAYA

\section{Penyusunan Kuesioner}

Pertanyaan dalam kuesioner ini dibuat dengan menggunakan skala likert dari pertanyaan yang diberikan kepada responden, yaitu dari angka 1-4 dimana angka 1 menunjukan pernyataan di dalam kuesioner tidak diterapkan bagi proyek yang dikerjakan oleh responden dan angka 4 menunjukan semakin tingginya penerapan sistem manajemen keselamatan dan kesehatan kerja (SMK3) pada proyek tersebut.

Prosedur yang digunakan dalam penyusunan kuesioner untuk mendapatkan data penerapan sistem manajemen keselamatan dan kesehatan kerja (SMK3) pada Proyek Pembangunan Rumah Sakit Sunan Kalijaga Demak:

1. Mengolah data dengan microsoft exel

2. Pertanyaan dalam kuesioner bersikan tentang hal-hal yang berkaitan dengan penerapan sistem manajemen keselamatan dan kesehatan kerja (SMK3) 
3. Kuesioner akan dibagikan ke 45 responden, dengan sasaran responden dari Kontraktor Lembaran kuesioner ini merupakan hasil dari kumpulan indikator-indikator penelitian yang dijabarkan lalu diubah menjadi pertanyaan-pertanyaan. Jawaban dari pertanyan berisikan angka yang berguna sebagai penentu seberapakah tingkat penerapan sistem manajemen keselamatan dan kesehatan kerja (SMK3) pada Proyek Pembangunan Rumah Sakit Sunan Kalijaga Demak.

1. Bagian $A$

Berisi dengan data responden meliputi profil perusahaan seperti nama, nilai proyek terbesar yang pernah ditangani, pendidikan terakhir, pengalaman kerja proyek, jabatan dan rata-rata durasi yang dipekerjakan.

2. Berisi tentang kuesioner bagaimana penerapan sistem manajemen keselamatan dan kesehatan kerja ( SMK3 ) pada proyek pembangunan Gedung Paru RSUD Sunan Kalijaga Kab.Demak .

Variabel tentang penerapan sistem manajemen Keselamatan Dan Kesehatan Kerja ( SMK 3 ) dengan skala 1 sampai 4 dengan penilaian sebagai berikut :

$$
\begin{aligned}
& 1=\text { Tidak Diterapkan }(\text { TD }) \\
& 2=\text { Kurang Diterapkan ( KD ) } \\
& 3=\text { Diterapkan }(D) \\
& 4=\text { Sangat Diterapkan }(S D)
\end{aligned}
$$

Menganalisa data dengan menentukan hasil rata - rata pada survei responden sebagai berikut :

$i=n$
$\sum_{\mathrm{X}=\frac{i=1}{n}} x i$

Dimana : $\quad x=$ rata - rata ukuran nilai faktor

$\mathrm{Xi}=$ ukuran nilai faktor responden ke- 1

$\mathrm{N}$ = jumlah responden

Menganalisa data untuk menentukan urutan rangking dari hasil kuisioner dengan menghitung nilai indeks kepentingan relative (IKR)

Untuk mendapatkan nilai IKR menggunakan rumus :

Dimana : IKR = Indeks kepentingan relatif

$$
I K R=\frac{X}{M}
$$

$\mathrm{M}=$ Jangkauan nilai faktor

$\mathrm{N}=4$

Variabel yang memiliki nilai IKR tertinggi diberi rangking 1 (satu), demikian seterusnya dengan nilai IKR terendah secara berurutan. Apabila terdapat dua atau lebih dari nilai IKR yang sama, maka penentuan rangkingnya dengan cara menjumlah rangking-rangking yang akan mewakilinya, kemudian dibagi dengan banyaknya variabel yang memiliki nilai sama. Metodeanalisis ini akan sangat berguna untuk mengidentifikasi rangking responden dan member prioritas terhadap variabel study.

\section{Metode Penyimpulan Data}

Setelah nilai mean dan data diketahui, kemudian menentukan range untuk mengelompokan masing masing variabel. Dengan memberi 4 pilihan yang sesuai dengan tingkat kepentingan dan untuk kepentingan dilapangan.

Penarikan kesimpulan data dilakukan sebagai berikut :

1. Menentukan interval dari yang tidak diterapkan sampai yang sangat diterapkan dengan kriteria skor hasil analisa sebagai berikut :
a. Skor $3,25<\mathrm{x} \leq 4,0=$ Faktor Yang Sangat Diterapkan
b. Skor $2,50<x \leq 3,25=$ Faktor Yang Diterapkan
c. Skor $1,75<x \leq 2,50=$ Faktor Yang Kurang Diterapkan
d. Skor $1,00<x \leq 1,75=$ Faktor Yang Tidak Diterapkan

2. Berdasarkan urutan rangking skor nantinya diambil 4 variabel yang diterapkan dengan melihat rangking nilai teratas dari nilai faktor yang keluar didalam analisa tersebut.

\section{ANALISIS DATA}

Analisis deskriptif responden dalam laporan ini adalah analisis mengenai pengolahan data yang digunakan untuk memberi gambaran dari hasil jawaban yang diberikan oleh responden terhadap beberapa pertanyaan yang terdapat pada kuisioner. 


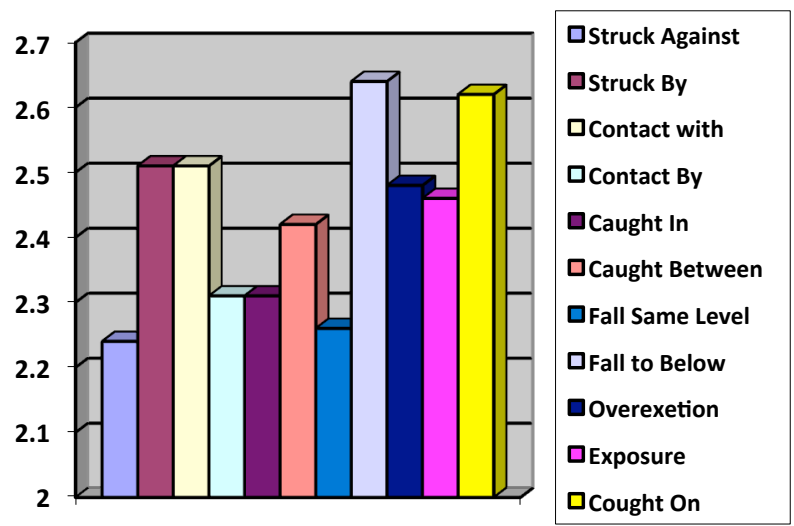

Sumber : Hasil perhitungan data primer yang diolah, 2018

Grafik 4.1 Hasil Kuesioner penerapan Sistem Manajemen Keselamatan dan Kesehatan Kerja (SMK3) dari kuesioner yang di isi oleh 45 responden pada dampak resiko Sistem Manajemen Keselamatan dan Kesehatan Kerja (SMK3).

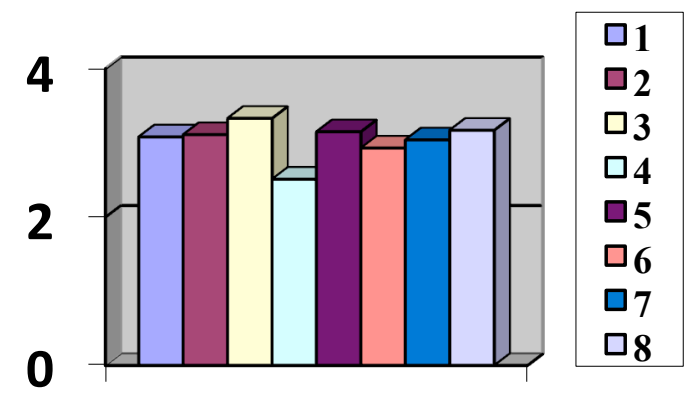

Sumber : Hasil perhitungan data primer yang diolah, 2018

Grafik 4.2 Hasil Kuesioner penerapan Sistem Manajemen Keselamatan dan Kesehatan Kerja (SMK3) dari kuesioner yang di isi oleh 45 responden pada proses pelaksanaan.

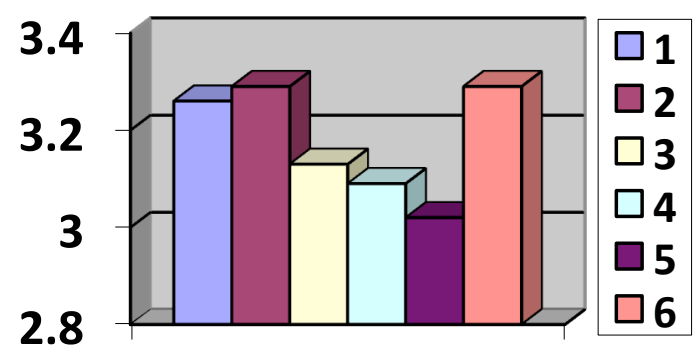

Sumber : Hasil perhitungan data primer yang diolah, 2018

Grafik 4.3 Hasil Kuesioner penerapan Sistem Manajemen Keselamatan dan Kesehatan Kerja (SMK3) dari kuesioner yang di isi oleh 45 responden pada proses evaluasi. 


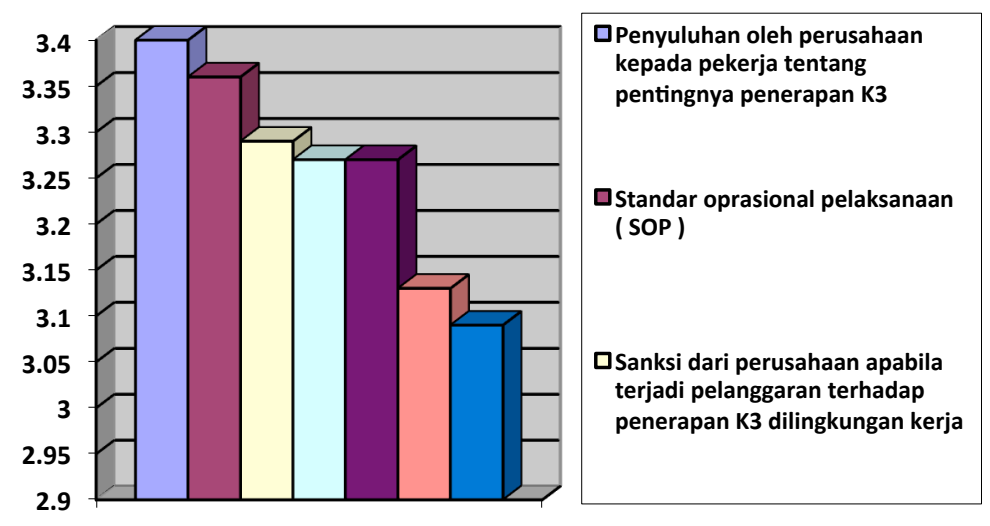

Sumber : Hasil perhitungan data primer yang diolah, 2018

Grafik 4.4 Hasil Kuesioner penerapan Sistem Manajemen Keselamatan dan Kesehatan Kerja (SMK3) dari kuesioner yang diisi oleh 45 responden pada proses pelaksanaan

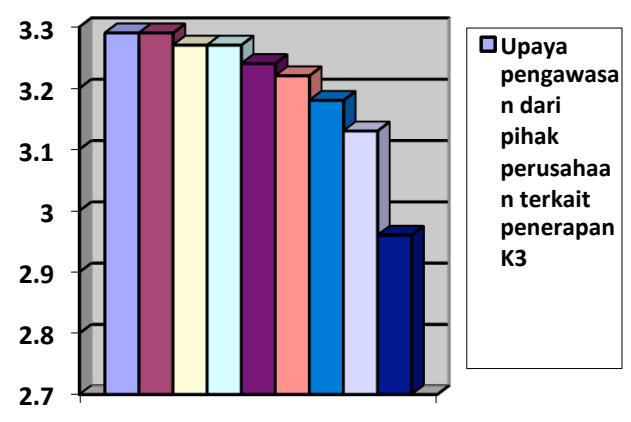

Sumber : Hasil perhitungan data primer yang diolh, 2018

Grafik 4.5 Hasil Kuesioner penerapan Sistem Manajemen Keselamatan dan Kesehatan Kerja (SMK3) dari kuesioner yang di isi oleh 45 responden pada proses pengendalian.

\section{Hasil Analisis Keseluruhan Penerapan SMK 3}

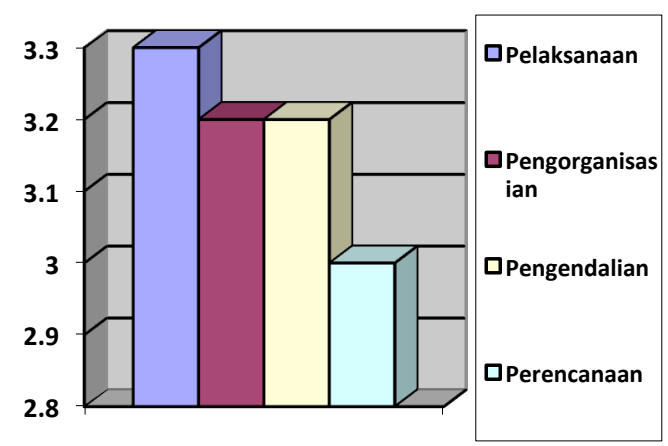

Sumber : Hasil perhitungan data primer yang diolah, 2018 
Dalam tinjauan tahahapan manajemen penerapan sistem manajemen kesehatan dan keselamatan kerja (SMK3) pada pembangunan gedung RSUD Sunan Kalijaga Demak, tahapan Pelaksanaan mempunyai tingkat penerapan yang paling tinggi, kemudian tahap pengendalian, perencanaan, dan terakhir pengorganisasian. Walaupun dengan tingkat perbedaan tidak terlalu besar.

\section{KESIMPULAN DAN SARAN \\ Kesimpulan}

Berdasarkan hasil penelitian yang telah di lakukan pada pelaksanaan proyek gedung RSUD Sunan Kalijaga Demak bahwa secara keseluruhan dampak resiko jika SMK3 tidak diterapkan adalah jarang terjadi, mengingat resiko yang paling tinggi terjadi adalah 'Fall to bellow'. Sedangkan resiko kecelakaan yang paling kecil adalah 'Struck Againt'. Pada Penerapan Sistem Manajemen Kesehatan Dan Keselamatan Kerja (SMK3) pada pelaksanaan proyek gedung RSUD Sunan Kalijaga Demak telah diterapkan dengan baik oleh pihak perusahaan jasa konstruksi, hal tersebut dapat diketahui dari hasil survei yang dilakukan dengan cara membagikan kuesioner.

\section{Saran}

Dari beberapa kesimpulan di atas maka didapatkan beberapa saran dibawah ini;

1. Sebaiknya dalam pelaksanaa pembangunan proyek gedung RSUD Sunan Kalijaga Demak terdapat rambu-rambu atau pembatas pada saat pelaksanaan supaya tidak terjadi kecelakaan seperti terbentur pipa, membentur bagian yang tajam, terpeleset dan terjatuh. Fungsinya sebagai tanda peringatan agar pada saat pelaksanaan para pekerja tidak mengalami kecelakaan kerja.

2. Pada proses pekerjaan di ketinggian terdapat potensi bahaya seperti terjatuh dari ketinggian, maka dari itu pekerja seharusnya di lengkapi dengan peralatan safety seperti 'Safety Body Harness' (Tali keselamatan), Safety Helmet (Alat pelindung kepala), Safety Shoes guna untuk keamanan pekerja supaya tidak terjadi kecelakaan terjatuh dari ketinggian.

3. Sebaiknya sebelum melakukan pekerjaan pekerja lebih berhati-hati saat mengangkat, menarik dan mendorong agar tidak terjadi kecelakaan kerja.

\section{DAFTAR PUSTAKA}

Bobby, Rocky Kani. 2013. Keselamatan dan Kesehatan Kerja Pada Pelaksanaan Peoyek Konstruksi (Studi Kasus : Proyek PT. TRAKINDO UTAMA). Manado: Universitas Sam Ratulangi.

Fisu, Arifuddin Rachmad. 2014. Analisis Resiko Kesehatan dan Keselamatan Kerja pada Proyek Pembangunan Rumah Sakit Stella Maris Makasar. Makasar: Universitas Hasanuddin.

Luckyta, Dhinar Tiara, dan Sri Gunani Partiwi. 2012. Evaluasi dan Perancangan Sistem Manajemen Keselamatan dan Kesehatan Kerja (SMK3) dalam Rangka Perbaikan Safety Behaviour Pekerja (Studi Kasus : PT. X Sidoarjo). Surabaya: Institute Teknologi Sepuluh Nopember (ITS).

Pangkey, Febyana. 2012. Penerapan Sistem Manajemen Keselamatan dan Kesehatan Kerja(SMK3) Pada Proyek Konstruksi di Indonesia. Manado: Universitas Sam Ratulangi.

Republik Indonesia. 1970. Undang-Undang Republik Indonesia Nomor 01 Tahun 1970 Tentang Keselamatan Kerja. Sekretariat Negara. Jakarta.

Republik Indonesia. 1993. Keputusan Menteri Tenaga Kerja Nomor KEP-463/MEN/1993 Tentang Pola Gerakan Nasional Membudayakan Keselamatan dan Kesehatan Kerja. Jakarta. 